\title{
MIX TEKNIK ECOPRINT DAN TEKNIK BATIK BERBAHAN WARNA TUMBUHAN DALAM PENCIPTAAN KARYA SENI TEKSTIL
}

\author{
Djandjang Purwo Sedjati ${ }^{1}$ (mrs.djandjang@gmail.com, Institut Seni Indonesia Yogyakarta) \\ Vincentia Tunjung Sari²
}

\begin{abstract}
Enactment of batik as cultural heritage of humanity's oral and non-material (Masterpieces of the Oral and Intangible Heritage of Humanity) by UNESCO on 2 October 2009 and establishment of Yogyakarta as the World Batik City by the World Craft Council. Making batik art back alive in the community and relief for batik avoid ownership of the nation and other countries. On the other hand, batik have to deal with the demands and tastes of the dynamics of today's society, batik have to deal with requests or demands of society will be new products that can satisfy their desires. Not only the need for fashion and interior devices are always evolving but also the needs of the works which can give the inner satisfaction. Thus, the necessary creations of new creative and innovative in order to meet the needs of consumers and the market. Departing from the above description, there is interest in creating art creative by exploring and incorporating ecoprint and batik techniques into the work of textile art. To collect the data used library method and observation method. As for the implementation use methods such as Methods Practiced Based Research (Malins, Ure, and Gray) to acquire new knowledge through practical research and practice results. Art Craft Creation Method Pattern Gustami Three Phase Six Steps to dig a source of ideas and design. Experimental methods and Improvisation is also author to gain new knowledge from experiments conducted mainly on ecoprint. In this creation, will be performed or composed stylized leaf shapes teak, guava, teak garden, breadfruit and leaves are used as a material lanang ecoprint with batik technique and then collaborated with ecoprint techniques. In batik will be applied coloring of the fruit keben. There are 3 types of textile art works to be made that the stole and scraf as two functional work and wall hanging or wall hangings as works of art expression.
\end{abstract}

Keywords: ecoprint, engineering, plant color, creation, textile works

\section{ABSTRAK}

Ditetapkannya batik sebagai warisan kemanusiaan untuk budaya lisan dan non bendawi (Masterpieces of the Oral and Intangible Heritage of Humanity) oleh UNESCO pada tanggal 2 Oktober 2009 dan ditetapkannya Yogyakarta sebagai Kota Batik Dunia oleh World Craft Council. Menjadikan seni batik kembali bergairah di tengah masyarakat sekaligus melegakan karena batik terhindar dari kepemilikan atas bangsa dan negara lain. Disisi lain, batik harus berhadapan dengan tuntutan dan dinamika selera masyarakat masa kini, batik harus berhadapan dengan permintaan atau tuntutan masyarakat akan produk-produk baru yang dapat memenuhi keinginan mereka. Tidak hanya kebutuhan untuk fashion dan perangkat interior yang selalu berkembang tetapi juga kebutuhan 
karya-karya yang dapat memberi kepuasan batin. Dengan demikian, diperlukan ciptaan-ciptaan baru yang kreatif dan inovatif dalam rangka untuk memenuhi kebutuhan konsumen dan pasar. Berangkat dari uraian tersebut diatas, muncul ketertarikan untuk menciptakan karya seni kreatif dengan mengeksplorasi dan menggabungkan teknik ecoprint dan batik ke dalam karya seni tekstil. Untuk mengumpulkan data digunakan metode pustaka dan metode observasi. Adapun pada pelaksanaannya digunakan metode antara lain Metode Practiced Based Research (Malins, Ure, dan Gray) untuk memperoleh pengetahuan baru melalui praktek riset dan hasil praktek. Metode Penciptaan Seni Kriya Pola Tiga Tahap Enam Langkah Gustami untuk menggali sumber ide dan perancangan. Metode Eksperimen dan Improvisasi juga dilakukan penulis untuk mendapatkan pengetahuan baru dari eksperimen yang dilakukan terutama pada ecoprint. Pada penciptaan ini, akan dilakukan stilisasi atau menggubah bentuk daun jati, jambu batu, jati kebon, sukun dan daun pohon lanang digunakan sebagai material ecoprint dengan teknik batik dan kemudian dikolaborasikan dengan teknik ecoprint. Pada batik akan diterapkan pewarna dari buah keben. Ada 3 jenis karya seni tekstil yang akan dibuat yaitu stola dan scraf sebagai dua karya fungsional dan wall hanging atau hiasan dinding sebagai karya seni ekspresi.

\section{Kata kunci: ecoprint, teknik , warna tumbuhan, penciptaan, karya tekstil}

\section{PENDAHULUAN}

Telah kita ketahui bersama bahwa batik merupakan warisan nenek moyang yang tak ternilai harganya. Dalam sejarah keberadaannya yang mengalami pasang surut, batik menjadi sandaran bagi sebagian masyarakat Indonesia untuk mencari nafkah, menjadi salah satu kegiatan ekonomi yang menghidupi banyak orang. Seiring dengan perkembangan jaman, maka tuntutan kebutuhan pun berkembang pula, sehingga memerlukan pemenuh kebutuhan tersebut. Pada awalnya batik yang berfungsi sebagai pemenuh kebutuhan masyarakat yang mecakup sandang atau busana tradisional dan keperluan upacara adat daur hidup kini berkembang sebagai busana sehari- hari (busana modern), barang- barang fashion atau elemen interior, bahkan batik menjadi pendukung utama sektor pariwisata yang sangat potensial baik sebagai cenderamata ataupun menjadi acara kunjungan wisata batik dimana wisatawan yang berkunjung ketempat kegiatan produksi batik dapat ikut mempraktekkan cara pembuatan batik.
Tidak dapat dipungkiri bahwa batik Indonesia sangat digemari dan dikagumi tidak saja oleh bangsa kita sendiri tetapi bangsa asing pun menggemari dan mengagumi batik karena keunikannya, sehingga batik Indonesia dapat dikatakan sudah menginternasional. Dengan ditetapkannya batik sebagai warisan kemanusiaan untuk budaya lisan dan non bendawi (Masterpieces of the Oral and Intangible Heritage of Humanity) oleh UNESCO pada tanggal 2 oktober 2009 tentu saja kita sambut baik, sebab pengakuan ini sekaligus sebagai bentuk pengakuan budaya Indonesia sebagai bagian dari budaya dunia. Pengakuan ini menjadikan seni batik kembali bergairah ditengah masyarakat sekaligus melegakan bangsa Indonesia bahwa batik terhindar dari kepemilikan atas bangsa atau negara lain. Perlu diketahui pengukuhan ini juga membawa konsekuensi bahwa batik harus tetap berkembang dalam kehidupan masyarakat Indonesia, sebab bila kehidupan batik tidak tumbuh dalam kehidupan masyarakat Indonesia, maka predikat tersebut akan dicabut kembali oleh UNESCO. Namun perlu diingat bahwa, walaupun Indonesia 
memperoleh pengakuan UNESCO sebagai asal batik dan menjadi produsen batik terbesar di dunia, Indonesia bukan satu-satunya negara penghasil batik. Banyak negara lain memiliki tradisi batik dan diantaranya juga ada yang menginginkan menjadi pusat batik antar bangsa.

Di era pasar bebas ini tentu ada hal-hal yang menimbulkan kekhawatiran, bagaimana menghadapi persoalan-persoalan yang muncul, misalnya produk- produk semacam batik dari luar negri yang masuk ke Nusantara sehingga menjadi persaingan.

Upaya - upaya penguatan dan revitalisasi batik telah banyak dilakukan, baik dilakukan oleh pihak pemerintah maupun swasta. Seperti misalnya batik diajarkan disekolah SD maupun SMP sebagai muatan lokal, bahkan ada yang menjadi mata pelajaran wajib diajarkan. Begitu pula pada usaha kecil menengah telah mendapat dukungan modal, pelatihan SDM sampai mengikuti pameran nasional yang didanai oleh pemerintah maupun swasta. Semua itu patut diberi dukungan. Namun bila bentuk motif, gaya dan fungsi berjalan stagnan dan tanpa pembaharuan maka akan menyebabkan kejenuhan pula.

Disisi lain, batik harus berhadapan dengan tuntutan dan dinamika selera masyarakat masa kini, batik harus berhadapan dengan permintaan atau tuntutan masyarakat akan produk-produk baru yang dapat memenuhi keinginan mereka. Tidak hanya kebutuhan untuk fashion dan perangkat interior yang selalu berkembang tetapi juga kebutuhan karya - karya yang dapat memberi kepuasan batin. Dengan demikian diperlukan ciptaan ciptaan baru yang kreatif dan inovatif dalam rangka untuk memenuhi kebutuhan konsumen dan pasar. Sebagai perancang penelitian ini sekaligus menjadi olah kemampuan dalam menciptakan sebuah karya seni tekstil yang kreatif dan inovatif. Kreatifitas adalah dimilikinya kemampuan atau daya untuk mencipta yang bersifat orisinal dan imajinatif. Diungkapkan oleh Anas (2011:11) Secara lebih terurai kreatifitas merupakan sebuah kemampuan untuk menggunakan imajinasi, wawasan dan kekuatan berfikir serta perasaan dan emosi untuk melahirkan sebuah gagasan baru.

Berangkat dari uraian tersebut diatas, muncul ketertarikan untuk menciptakan karya seni kreatif dengan mengeksplorasi dan menggabungkan teknik ecoprint dan batik kedalam karya seni tekstil. Bila dilihat dari jenis teknik pembuatannya, ecoprint dan batik merupakan hasil dari rekalatar. Rekalatar ecoprint adalah kain dari hasil reka latar melalui cetak dari bagian tumbuhan tertentu secara langsung melalui proses hammer dan atau steaming. Adapun reka latar batik adalah teknik menghias pada permukaan kain menggunakan perintang warna sejenis lilin yang disebut malam. Dalam hal ini antara ecoprint dan batik proses pelaksanaan pembuatannya berlawanan. Pada batik proses pewarnaannya, pewarna yang digunakan harus dalam keadaan dingin, sedangkan pewarnaan dalam ecoprint melalui pemanasan. Penggabungan dua teknik yang sangat berbeda ini merupakan hal yang penting dalam rangka pengembangan keteknikan untuk menghasilkan sebuah karya seni baru yang kreatif dan inovatif yang diharapkan dapat ditransfer ke mahasiswa dan masyarakat umum.

Pada penciptaan ini, akan dilakukan stilisasi atau menggubah bentuk daun jati, jambu batu, klengkeng, ketepeng, talok, bunga sepatu dan daun serta bunga yang diasumsikan dapat digunakan sebagai material ecoprint dengan teknik batik dan kemudian dikolaborasikan dengan teknik ecoprint. Sesuai dengan namanya ecoprint, maka yang dipakai dalam pencetakan warna adalah bahan alam yaitu tumbuh tumbuhan yang memiliki 
kandungan zat warna yang dapat dicetakkan pada permukaan kain, sedangan pada batik akan diterapkan pewarna dari buah keben. Penggunaan zat warna alam keben ini adalah memanfaatkan hasil penelitian sebelumnya. Ada 3 item jenis karya seni tekstil yang akan dibuat yaitu stola dan scarf sebagai dua karya fungsional dan wall hanging atau hiasan dinding sebagai karya seni ekspresi. Karya seni tekstil tersebutakan diaplikasikan pada kain sutra dengan gaya kreatif mengarah kontemporer. Digunakanannya zat warna alam sebagai upaya mengurangi pencemaran lingkungan akibat penggunaan zat warna sintetis. Rencana penciptaan tersebut sebagai bentuk kepedulian dalam rangka dukungan untuk mempertahankan status Indonesia sebagai Masterpieces of The Oral and Intangible Heritage of Humanity atau sebagai warisan budaya tak benda yang dikukuhkan sejak 2 Oktober 2009 oleh UNESCO.

Dari uraian latar belakang diatas, maka permasalahannya dapat dirumuskan sebagai berikut :

1. Bagaimana proses penciptaan karya kriya tekstil dengan mengkombinasikan teknik ecoprint dan batik, dengan bahan baku tumbuhan sehingga diperoleh metode yang tepat?

2. Bagaimana hasil yang diperoleh dari kombinasi dua teknik tersebut?

\section{METODE PENCIPTAAN}

\section{Metode Practiced Based Research}

Dalam penciptaan karya ini akan menggunakan metode Practice Based Research, penelitian berbasis praktek merupakan penyelidikan orisinil yang dilakukan guna memperoleh pengetahuan baru melalui praktek dan hasil praktek tersebut. Pada pengertian yang lebih dalam, disebutkan bahwa penelitian berbasis praktek merupakan penelitian yang paling tepat digunakan oleh pencipta karena pengetahuan baru yang didapat dari penelitian yang dilakukan dapat langsung diterapkan pada bidang bersangkutan dan peneliti melakukan yang terbaik dengan menggunakan kemampuan mereka dan pengetahuan yang telah dimiliki pada subyek kajian tersebut. (Malins, Ure, dan Gray:1996,1-2)

Penggunaan metode practised-based researchdalam proses penciptaan karya ini untuk proses eksekusinya menggunakan metode action (Lomax, 1996:10) dijelaskan bahwa "....penelitian tindakan adalah jalan untuk mendefinisikan dan mengimplementasikan perkembangan profesional yang relevan dengan bidangnya. Metode practiced based research danaction di atas akan dikombinasikan juga dengan metode penciptaan seni SP Gustami sebagai pelengkap dalam penyusunan tahapan-tahapan yang dilakukan pada pelaksanaan practice based research menggunakan pengalaman pribadi dan buku yang berisi tentang zat warna alam seperti pada buku Seni Kerajinan Batik Indonesia dan Batik Indonesia Mahakarya Penuh Pesona.

\section{Metode Penciptaan Seni Kriya Pola Tiga Tahap Enam Langkah Gustami SP}

Proses penciptaan karya seni dapat dilakukan melalui metode ilmiah yang direncanakan secara seksama, analitis, dan sistematis. Dalam kontek metodologis terdapat tiga tahap penciptaan karya seni yaitu Eksplorasi, Perancangan, dan Perwujudan. Dijelaskan oleh Gustami, tahapan metodenya sebegai berikut :

"Pertama, tahap eksplorasi meliputi aktivitas penjelajahan mengenai sumber ide dengan langkah identifikasi dan perumusan masalah, penelusuran, penggalian pengumpulan data dan referensi, berikut pengolahan dan analisis data untuk mendapatkan simpul penting konsep pemecahan masalah secara 
teoritis, yang hasilnya dipakai sebagai dasar perancangan. Kedua, tahap perancangan yang dibangun berdasarkan perolehan butir penting hasil analisis yang dirumuskan, diteruskan visualisasi gagasan dalam bentuk sketsa alternative, kemudian ditetapkan pilihan sketsa terbaik sebagai acuan reka bentuk atau dengan teknik menggambar yang berguna bagi perwujudan, bermula dari pembuatan model sesuai sketsa alternatif atau gambar teknik yang berguna bagi perwujudannya....Lebih lanjut langkah ketiga yakni tahap perancangan untuk menuangkan ide atau gagasan dari deskripsi verbal hasil analisis yang dilakukan kedalam bentuk visual dalam batas rancangan dua dimensional. Penuangan ide kreatif menjadi rnacangan dua dimensional itu dilakukan dengan pertimbangan berbagai aspek menyangkut kompleksitan nilai seni kriya, antara lain, aspek material, teknik, proses, metode, konstruksi, egonomi, keamanan, kenyamanan, keselarasan, keseimbangan, bentuk, unsure estetik, gaya, filosofi, pesan, makna, berikut fungsi social ekonomi dan budaya serta peluang masa depannya. (Gustami, Butir-Butir....2007, 329-333).

\section{Metode Eksperimen dan improvisasi}

Eksperimen uji coba dengan menggunakan bagian tumbuh tumbuhan seperti daun, bunga, dan buah yang dapat mencetak secara langsung pada kain. Pada pewarnaan batik kali ini penulis akan menggunakan pewarna buah keben yang sudah diteliti dan dipakai didalam pewarnaan batik pada penelitian sebelumnya. Penulis juga akan melakukan improvisasi bila pada tahap pelaksanaan menemukan ide ide baru sebagai variasi sepanjang sebagai penunjang karya menjadi lebih baik.

\section{Metode Pengumpulan Data}

Untuk mendapatkan data dan referensi dengan mencari sumber menggunakan metode pustaka dan metode observasi. Metode pustaka, yaitu mencari datamelalui buku, majalah, katalog, website maupun literature termasuk penelitian yang sifatnya kualitatif, data yang diambil adalah data kualitatif yang berkaitan dengan proses penciptaan dan tentang obyek penciptaan yaitu tanaman atau tumbuhsn sebagai material ecoprint. Metode observasi dipakai untuk mendapatkan data tentang obyek yang dijadikan sumber penciptaan, yaitu tentang tanaman atau tumbuhan sebagai material ecoprint.

\section{HASIL DAN PEMBAHASAN}

Dari metode pengumpulan data yang dilaksanakan didapatkan bagian-bagian tumbuhan yang digunakan dalam pembuatan ecoprint dan pewarnaan batik warna alam.

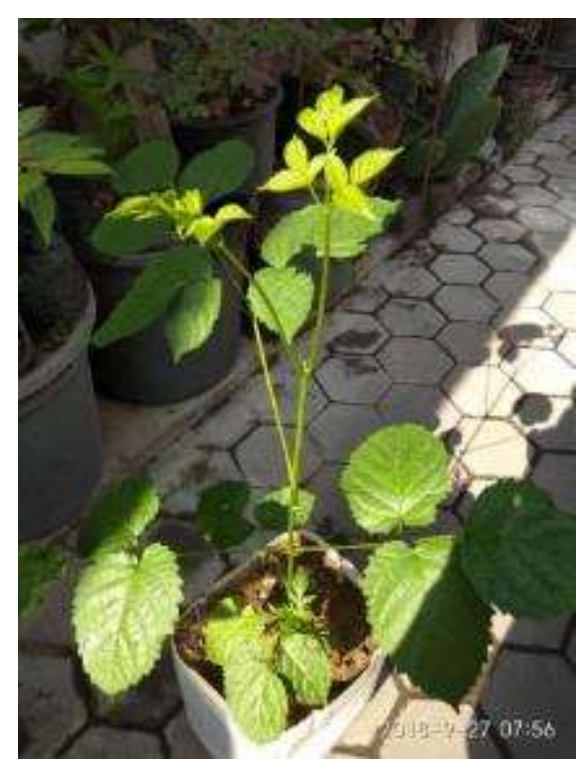




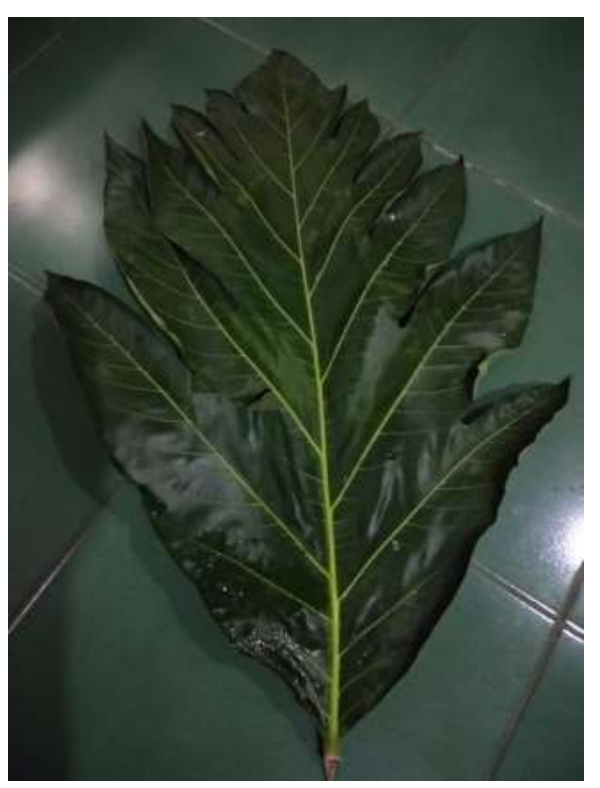

Gambar. Daun pohon Lanang dan daun Sukun
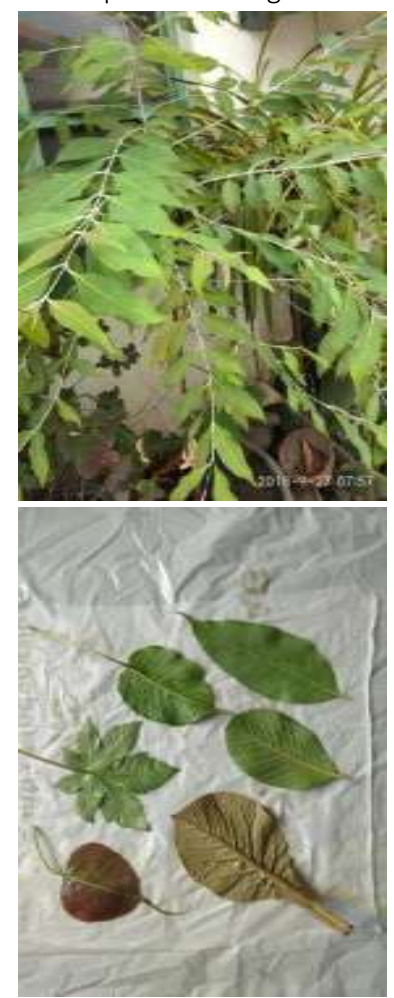

Gambar. Pohon Eucalyptus Rainbow, daun Jati, daun pohon Bodi, daun Jarak, daun Jambu Batu
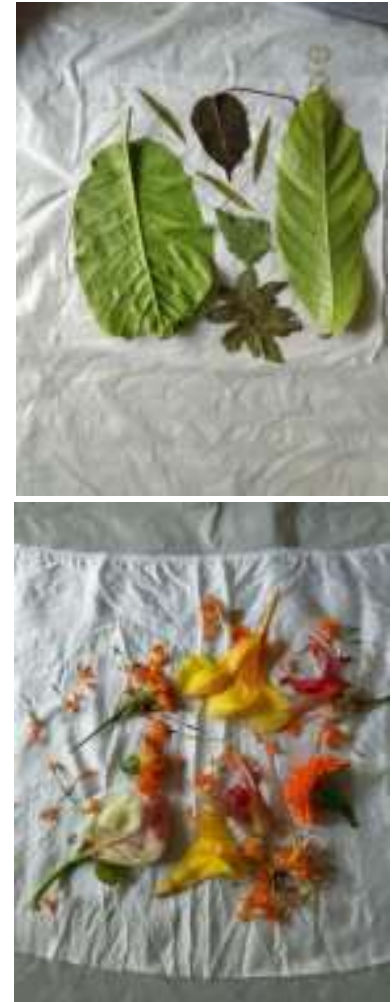

Gambar. Daun Jati Kebon, daun Kakao, daun Jarak, daun Kayu Putih, bunga Alamanda, bunga Kenikir, bunga Keben, bunga Patramenggala

\section{Metode Practiced Based Research dan Eksperiment}

Pada tahap ini dilakukan percobaan pembuatan ecoprint menggunakan daun jati, daun sukun, daun jambu, daun kakao, daun jati kebon, daun eukaliptus rainbow, daun pohon bodi, bunga kenikir, bunga patra menggala (bunga merak), bunga sepatu, bunga alamanda, bunga wora- wari dan buah Keben sebagai pewarnaan alam pada batik yang dibuat. Pada tahap ini dilakukan dua kali percobaan proses pembuatan mix teknik ecoprint dan batik dengan melakukan salah satunya dengan membuat ecoprint dahulu lalu proses batiknya dan yang lainnya dengan membuat batiknya dahulu lalu proses ecoprint. 

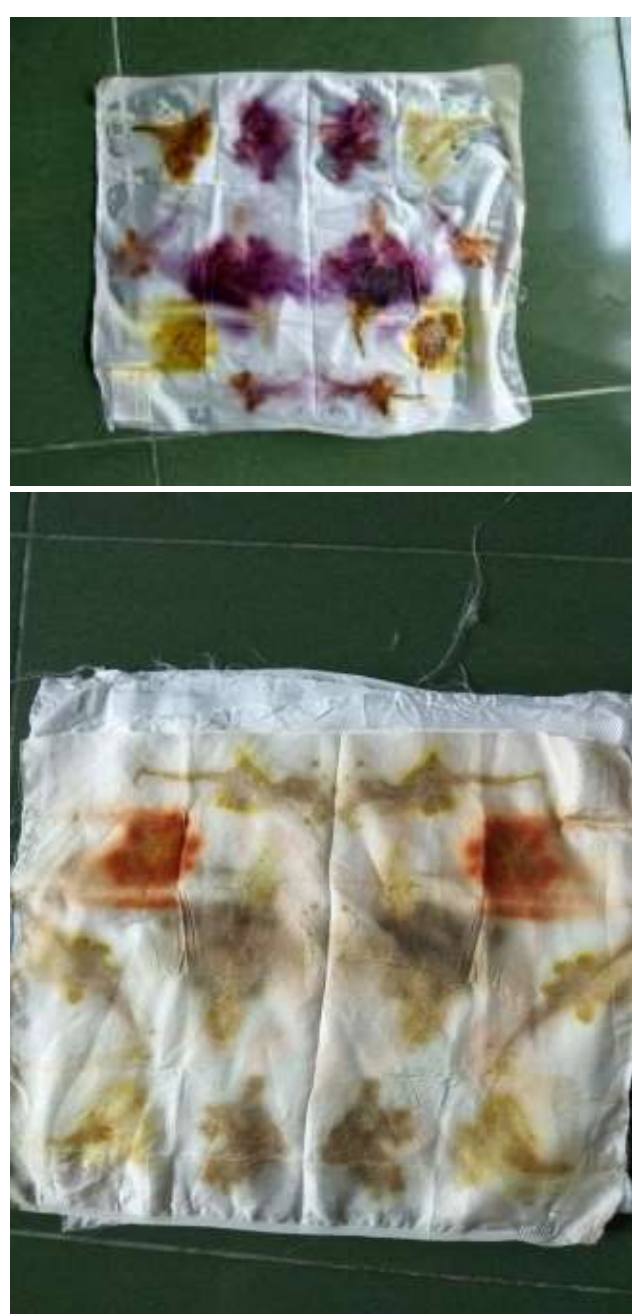

Gambar. Hasil Ecoprint bunga Sepatu, bunga Wora-wari, bunga Kenikir, bunga Alamanda, bunga Patramenggala sebelum dan setelah fiksasi

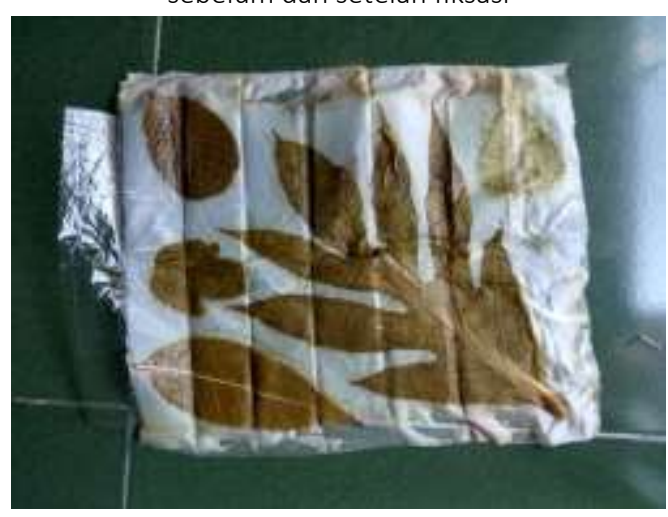

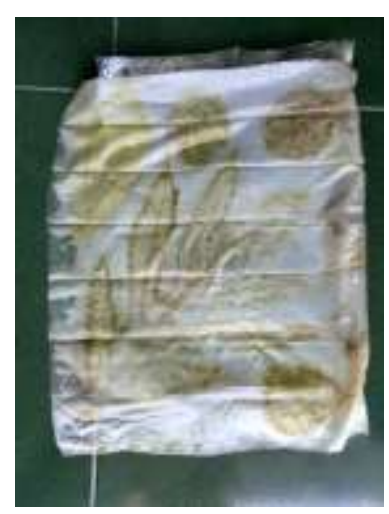

Gambar. Eksperimen Ecoprint dengan sistem pounding dan steaming setelah dikeluarkan, sebelum dan setelah fiksasi dengan kapur
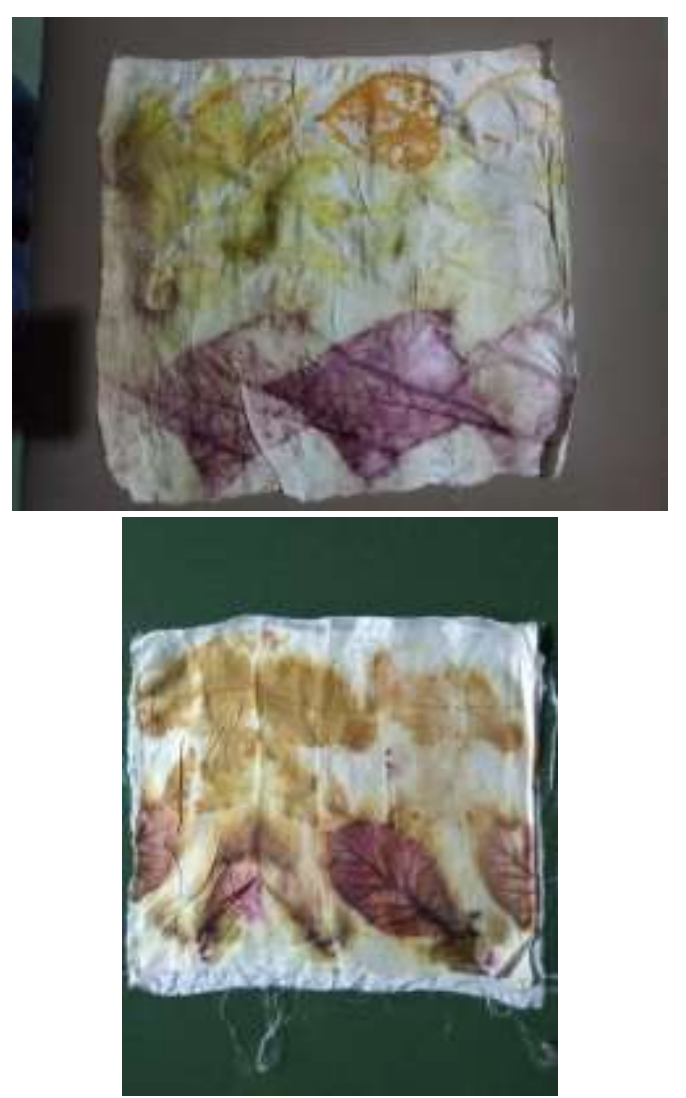

Gambar. Hasil Ecoprint Daun Jati, Daun Pohon Bodi, Daun Jarak, Daun Jambu Batu dan Ecoprint sebelum dibatik 


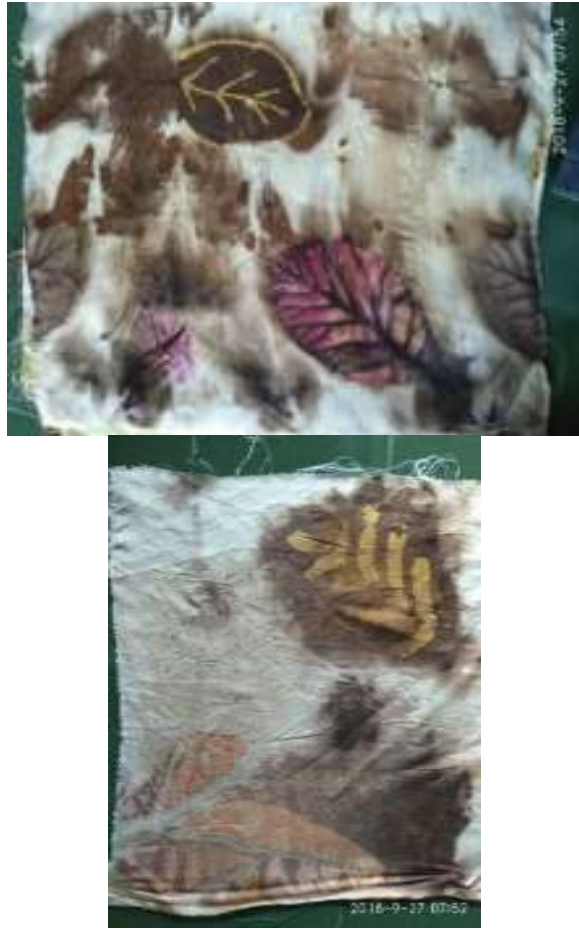

Gambar. Hasil Mix Ecoprint dengan Batik (Ecoprint yang dibatik)
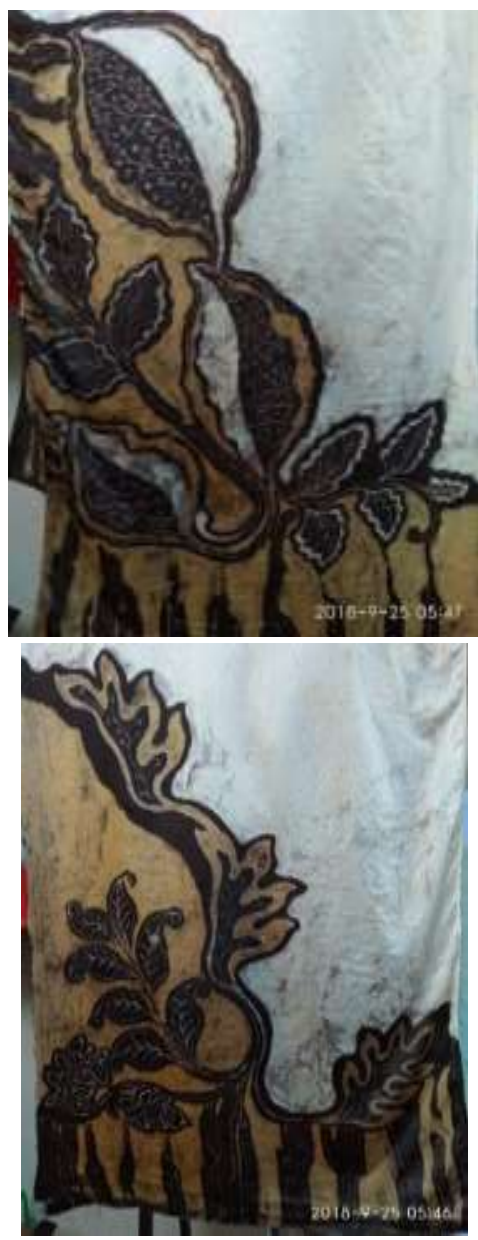

Gambar. Batik sebelum di Ecoprint
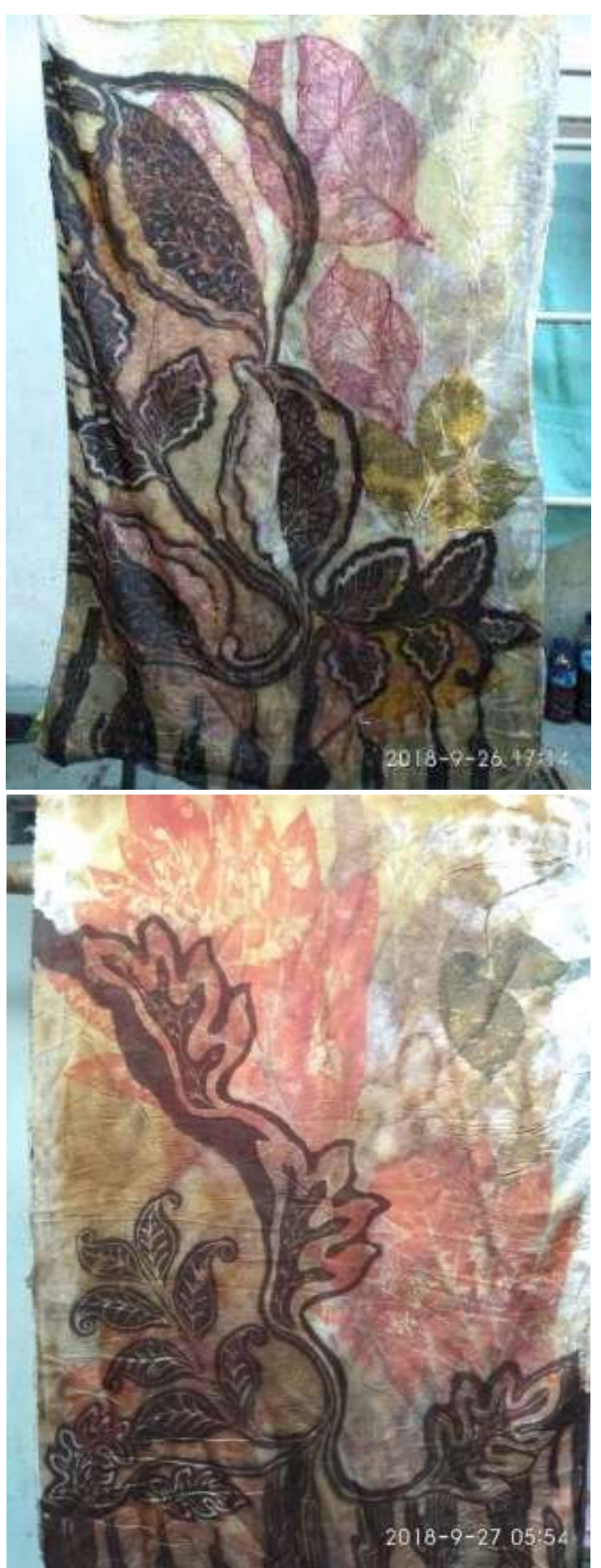

Gambar. Batik setelah di Ecoprint

\section{Perwujudan}

\section{Pembuatan Sketsa Rancangan Karya}

Membuat sket bagian-bagian dari daun jati, daun sukun, daun eucalyptus rainbow, daun jambu batu, dan daun pohon lanang. Sketsa awal berupa sket masing-masing. 

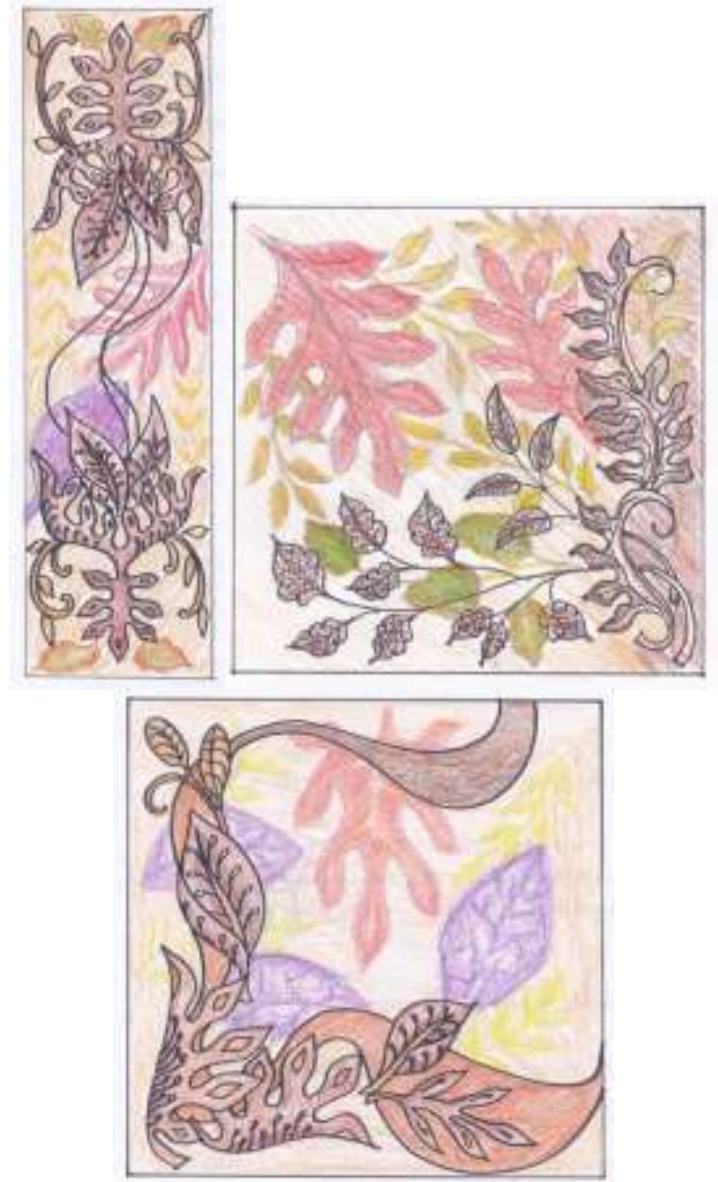

Gambar. Desain Alternatif Stola, Scraf 1 dan Scraf 2
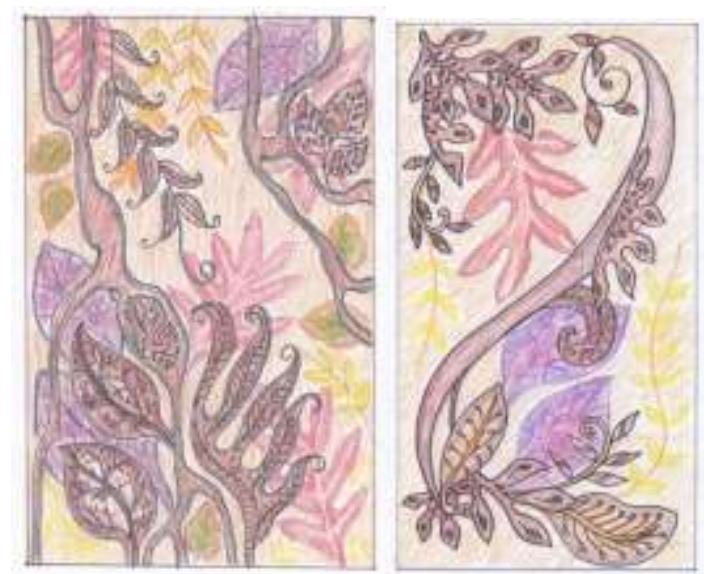

Gambar. Desain alternatif wallhanging 1dan 2

\section{Pengolahan Bahan}

Pada tahap ini bahan dasar (kain sutra) harus dimordant terlebih dahulu supaya nantinya warna alam dapat melekat pada kain dengan maksimal. Pengolahan ini dilakukan dengan cara merebus sutera dalam larutan tawas. Perbandingan tawas $100 \mathrm{gr}$ air (kurang lebih 1 liter) selama 1 jam kemudian didiamkan semalam dan esok paginya dicuci bersih dan dikeringkan dengan cara dianginanginkan.

\section{Pembuatan Batik}

Proses pemindahan desain dari kertas menuju ke kain

Motif yang sudah dirancang kemudian dipindah di kain sutera

dengan cara dijiplak. Pada pelaksanaan ini memerlukan waktu yang cukup lama. Hal ini di karenakan sifat sutera yang sangat licin sehingga ketika di gambar perlu kecermatan dan ketelatenan, penulis disini melakukan dengan hati-hati agar gambar tidak bergeser geser dan bentuk tidak berubah.

\section{Pencantingan}

Selesai pemindahan motif, kemudian kain dibatik (dicanting)

sesuai dengan gambar, pencantingan berupa klowong, tembok dan isen-isen. Proses pencantingan diatas kain sutera membutuhkan waktu yang lama karena sifat kain yang licin dan agak sulit untuk dibatik.

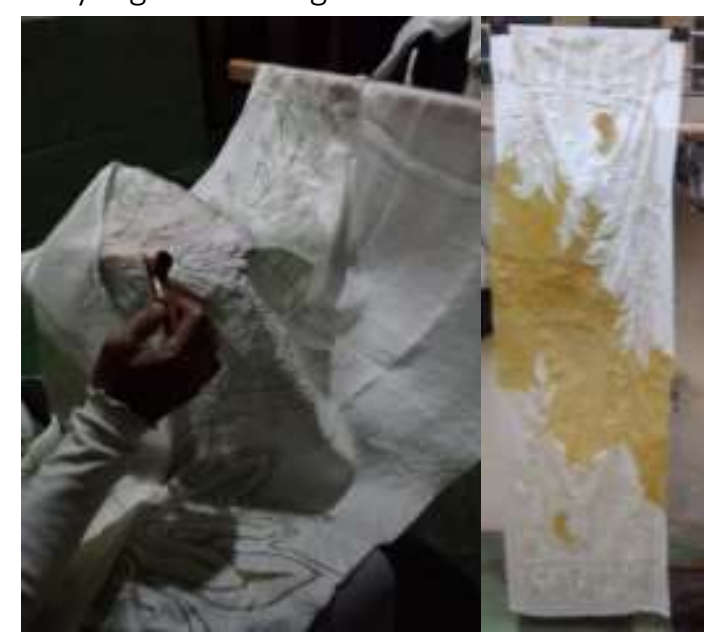

Gambar. Proses dan hasil pencantigan

\section{Proses pewarnaan batik}

Air rebusan buah keben yang sudah siap dipakai diletakkan di ember atau bak. Kain batikan dibasahi dahulu dengan air biasa yang dicampur dengan TRO, kemudian ditiriskan. Setelah tiris, kain dicelup kedalam air buah 
keben sampai semuanya terendam lebih kurang 15 menit, kemudian ditiriskan dan diangin-anginkan. Setelah kering direndam lagi di air buah keben, demikian dilakukan berkali kali paling sedikit 6 kali. Setelah kering pada pencelupan terakhir, kain di fiksasi atau dikunci dengan bahan pengunci kapur dan tunjung. Untuk mendapatkan warna coklat kain direndam dalam larutan air kapur, sedang untuk mendapatkan warna abu abu atau hitam kain direndam dalam larutan tunjung. Perendaman dilakukan selama 10-15 menit.
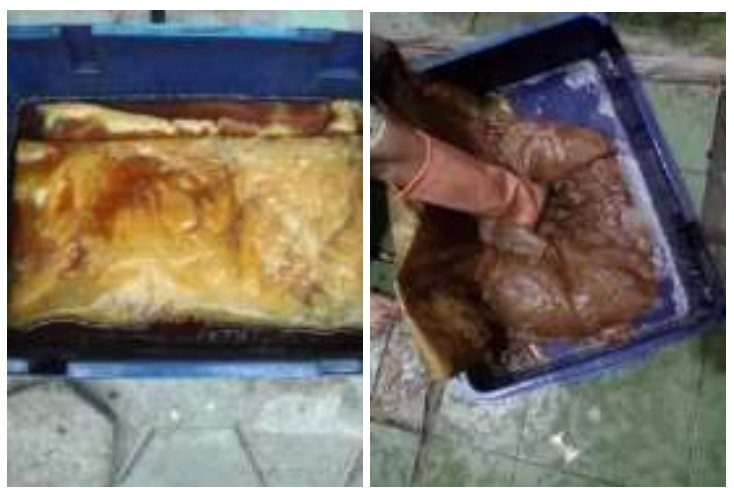

Gambar. Proses Pencelupan dan fksasi dengan kapur

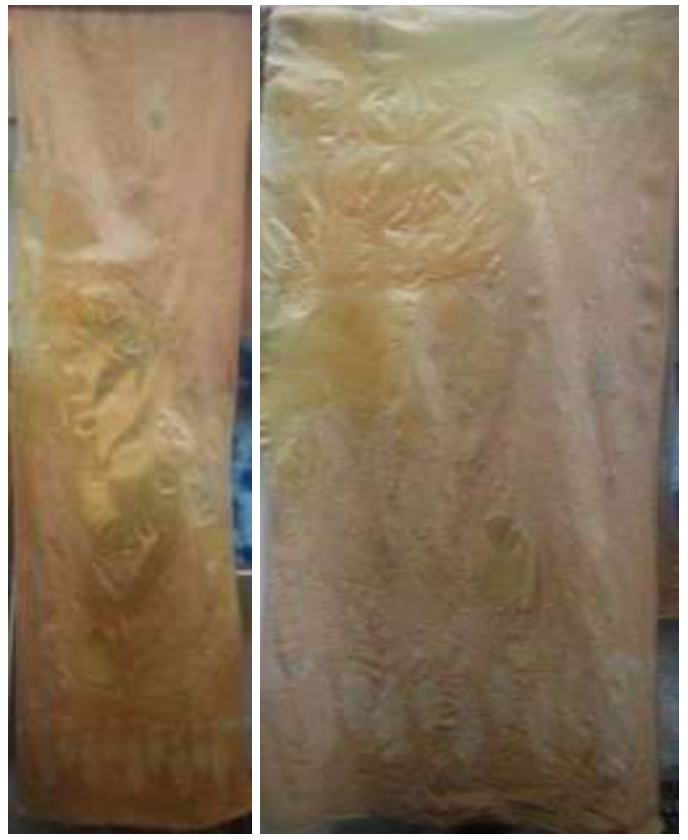

Gambar. Hasil pencelupan warna pertama dan detail desain

\section{Pelorodan}

Pada tahap ini merupakan tahap terakhir dari rangkaian tahapan dalam proses batik, yaitu melepas malam dari kain. Caranya adalah dengan mendidihkan 10 liter air dalam panci email besar yang ditambah 1ons soda abu dan 1ons tepung kanji yang sudah dilarutkan dengan air. Dalam keadaan air mendidih kain dimasukkan dan direbus sampai malam lepas, kemudian diangkat dan dicuci air bersih. Bila belum bersih, diulang sampai malam bersih tidak ada yang menempel pada kain.

\section{Pembuatan Ecoprint}

Dalam eksperimen pembuatan mix teknik ecoprint dan batik yang dilakukan proses ini dilakukan dengan merendam kain ke dalam larutan cuka yang kemudian ditempeli dengan daun dan bunga yang kemudian dilipat dan ditekan dengan dua buah kayu dan digulung pada potongan bambu. Setelah itu, kain dikukus selama 1,5-2 jam lalu ditunggu minimal 5 jam sebelum dibuka. Kemudian kain yang sudah dibuka difiksasi menggunakan kapur.

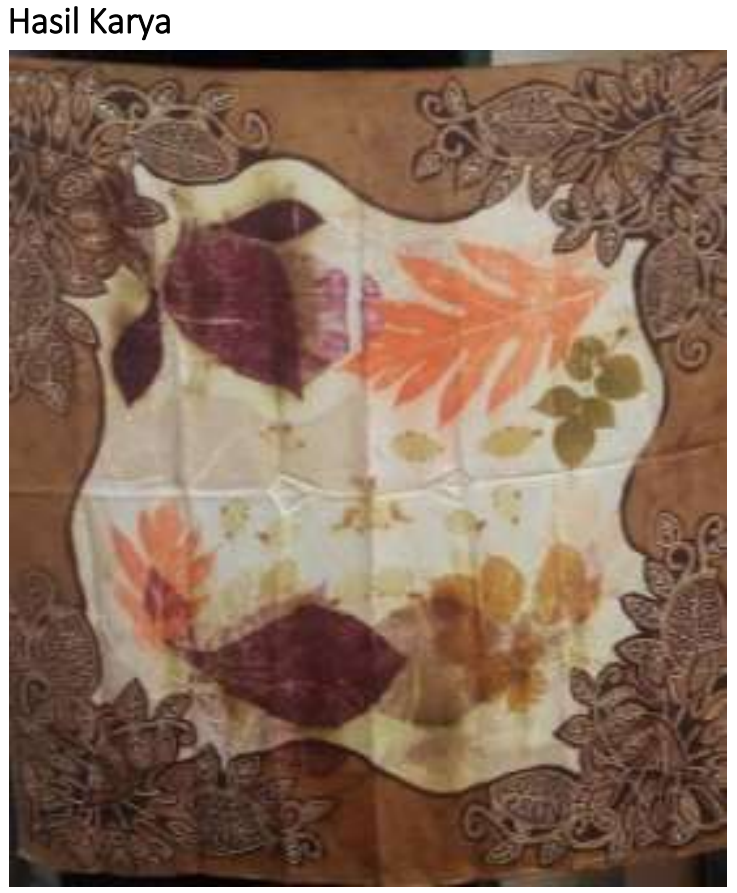

Gambar. Hasil karya scraf 


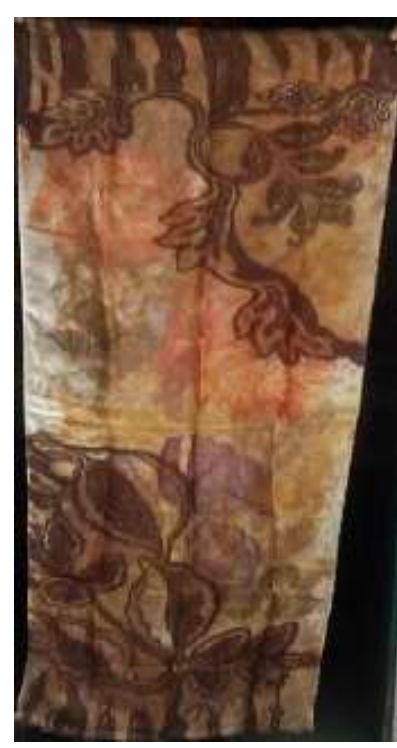

Gambar. Hasil karya stola

\section{PENUTUP}

Beberapa tahap dilakukan untuk mengeksplorasi mix teknik ecoprint dan teknik batik melalui eksperimen sesuai dengan metode yang digunakanya itu pactriced based research. Dari beberapa tahapan tersebut yang pertama adalah eksperimen untuk mendapatkan jenis daun maupun bunga yang bisa tercetak bentuknya (print) pada kain sutra. Yang kedua adalah eksperimen mix teknik ecoprint dengan batik. Yang ketiga adalah eksperimen mix teknik batik dengan ecoprint.

Dari hasil eksperimen tersebut didapatkan daun dan bunga yang bisa tercetak dan yang tidak bisa tercetak pada kain sutra. Dari hasil tersebut hanya daun Jati, daun pohon Lanang dan daun Sukun yang tercetak paling jelas, sedangkan daun Jambu batu, dan daun Eucalyptus Rainbow yang bisa tercetak dengan warna yang kurang jelas tapi masih bisa dikenali. Adapun bunga tidak ada sama sekali yang bisa tercetak dengan baik.

Proses eksperimen melalui mix teknik ecoprint dengan batik hasilnya kurang memuaskan karena hasil warna ecoprint menjadi pudar. Adapun eksperimen mix teknik batik dengan ecoprint mendapatkan hasil yang lebih baik.
Dengan demikian, dalam pembuatan karya mix teknik ecoprint dengan batik akan dilaksanakan dengan cara membatik dahulu dan diecoprint kemudian.

\section{DAFTAR PUSTAKA}

Anas, Biranul, "Batik dalam Dinamika Budaya”, Proceding Seminar Nasional Batik, Prodi. Seni Kerajinan FBS UNY, 2011

Dharsono, S. Kartika, SeniRupa Modern, Rekayasa Sains, Bandung, 2004

Gardjito, Murdijati (Ed.), Batik Indonesia Mahakarya Penuh Pesona, Kaki langit Kencana, Jakarta, 2015

Gustami Sp., Butir-Butir Mutiara Estetika Timur: Ide Dasar Penciptaan Seni Kriya Indonesia, Prasista, Yogyakarta, 2007 Nukilan Seni Ornamen Indonesia, Jurusan Kriya Fakultas Seni Rupa ISI Yogyakarta, 2008

Malins, J., Ure, J. Dan Gray, C., The Gap: Addressing Practised-Based Research Training Requirements for Designers, The Robert Gordon University, Aberden, UK

Mcniff,J., Lomax, P., dan Whitehead, J., You and Your Action Research Project, Hyde Publication, UK

Sachari, Agus, Pengantar Metodologi Penelitian Budaya Rupa, Jakarta, Erlangga, 2005

Desain-Desain Gaya dan Realitas, Indonesia:Studi Desain ITB,1987.

Sp., Soedarso, Tinjauan Seni Sebuah Pengantar untuk Apresiasi Seni, Saku Dayar Sana, Yogyakarta, 1990.

Trilogi Seni :Penciptaan Eksistensi dan Kegunaan Seni, Badan Penerbit ISI Yogyakarta, 2006, 82.

Susanto, Sewan, Seni Kerajinan Batik Indonesia, BBKB, Yogyakarta, 1980 